\title{
Designing ARVs Patent Pool Up to Trade \& Policy Evolutionary Dynamics
}

\author{
Daniele Dionisio*, ${ }^{*}$ Vincenzo Racalbuto ${ }^{2}$ and Daniela Messeri ${ }^{3}$
}

\author{
I “Access to Drugs: International Policies" - CLIA (Italian Network for International Fight against AIDS), Italian \\ Society for Infectious and Tropical Diseases (SIMIT), Division of Infectious Diseases, Pistoia Hospital, Pistoia, Italy \\ ${ }^{2}$ Italian Cooperation Headquarters at the Italian Ministry of Foreign Affairs, CLIA, Directorate General for \\ Development Cooperation, Rome, Italy \\ ${ }^{3}$ Division of Infectious Diseases, Pistoia Hospital, Pistoia, Italy
}

\begin{abstract}
Patent pools for second and third-line Fixed Dose Combination (FDC) antiretroviral drugs (ARVs) should not be delayed as they are instrumental to urgent public health needs in the under-served markets.

Nonetheless, multinational originator companies still seem to perceive patent pooling for ARVs as a minefield that would offer the generic competitors lots of deeply exploitable opportunities, to the detriment of patent owner's rights.

This paper analyses the brand industry concerns, while looking for a strategy up to a really equitable and free world market, without any discrimination between end-users in wealthy and resource-limited countries.

This strategy would urge partnerships between originator companies first to make newer FDC ARVs quickly available and allow patent pool agreements with generic counterparts to be negotiated straight afterwards.

The patent pool strategy highlighted in this paper would assert the primacy of health over for-profit policies, while aligning with the $61^{\text {st }}$ WHO's Assembly recommendations and G7, G8 and World Trade Organisation's warnings and pledges against trade protectionism.
\end{abstract}

\section{MEETING THE NEED}

Patent pools are part of May 2008-adopted World Health Organization-WHO's Global Strategy on Public Health, Innovation and Intellectual Property to help increase access to medicines [1].

As far as antiretroviral (ARV) treatments are concerned, quantified benefits of the pools are expected to include, through skyrocketed market competition, substantially lower prices for second and third-line new Fixed Dose Combination (FDC) ARV formulations [2].

Patent pools for antiretrovirals (ARVs) cannot be given up or delayed further owing to urgent health needs in the under-served markets: full availability of appropriate and affordable FDC ARVs including second and third-lines is top priority for the worst-off in the developing countries [35].

Attaining this goal would effectively counter bitter reality witnessing that ARVs are primarily developed for wealthy country markets, while trials are focused on coping with registration requirements in these countries and key research matters for resource-constrained populations are often only tackled long after drug registration and rolling-out in the Europe and USA [6].

*Address correspondence to this author at the Infectious Disease Division, Pistoia Hospital, Piazza Giovanni XXIII 1, Pistoia, Italy; Tel: 0039-0573352324; Fax: 0039-0573-352309;

E-mails: d.dionisio@tiscali.it d.dionisio@usl3.toscana.it
Pooling ARV drug patents would carry out WHO's calls on appropriately needed new FDC ARVs [7-9]. These may include adding heat-stable protease inhibitor (PI) ritonavir (RTV) to each atazanavir (ATV), darunavir (DRV), or saquinavir (SQV) PIs, or variously combining raltegravir (or other integrase inhibitors) with either newer heat-stable RTV-boosted PIs (also unboosted in the case of ATV) or the non-nucleoside reverse-transcriptase inhibitor (NNRTI) etravirine (pending results from raltegravir-novel NNRTI rilpivirine interaction studies). For paediatric purposes, combinations including heat-stable $35 \mathrm{mg}$ emtricitabine tablets should be taken into account [6-9].

\section{LOOKING INTO BRAND INDUSTRY CONCERNS}

High-tech patent pool models not pertaining to health sectors (i.e., those involving technologies that require common standards, such as MPEG-2, DVD-video, DVDROM and radio) have already gained agreement as fitting instruments to convey shared interests between peers towards increasing profits and marketing power [10].

Medicines, instead, are trickier domain, particularly where ARVs are concerned. Actually, the situation for ARVS is different because their development remains profitable for the Western market.

Brand industry, indeed, still seems to perceive patent pooling for ARVs as a minefield that would offer the generic competitors lots of deeply exploitable opportunities, to the detriment of patent owner's rights [11-14].

Briefly, pooling ARV drug patents looks like it would be felt as a forcing possibly resulting in slashed brand industry 
profits in the under-served markets, in illegal flows of generic new FDC ARVs into the wealthy markets, in unbalanced boosting on innovation, development and research project activities currently pushed by generic drug manufacturers (mainly from India, China, Brazil, SouthAfrica and Thailand) as a premise to enhanced competion and forays into the Western markets. Again, pooling patents could be felt as a risk to waive opportunities for fruitful voluntary license-VL agreements, and as a threat to keeping up brand leadership in research and development (R\&D) of new therapeutic agents [11-14].

Brand industry feelings on HIV drug patent pools likely take into account trade\&policy plus R\&D tricky balances on evolutionary world chessboard, where China's and India's paces look very fast [15].

With regard to China, feelings may include awareness that today 2,500 life sciences faculty at US research universities are native Chinese, as are an estimated $10 \%$ to $20 \%$ of scientists in the labs of US drug and biotech companies: now, in a steadily increasing reverse migration to China, these US-trained Chinese scientists are setting up high-standard biotech start-ups, contract-research companies, and university labs on their native mainland [16].

In the meanwhile, the number of patent applications from China and India filed at the US patent Office has been rising rapidly [4].

China and, to a lesser extent, India are, moreover, the major suppliers of active pharmaceutical ingredients (APIs) for ARVs to the developed and developing world [15]. This gives both countries power in influencing ARV drug price evolution. Indeed, as APIs do represent the largest components of direct manufacturing costs (55-99\%), significant decreases in the price of ARVs will depend on a concomitant decrease in the cost of APIs [17]. Substantial research, deeply involving industries in middle-income countries, is dealing now with driving API cost reduction for access [18].

Feelings above couple with the concerns bound up with threats to patent applications for brand ARVs, as per recently opposed refusals by India (including darunavir and tenofovir) and Brazil and predictably hard patentability in India of novel Abbott's heat-stable RTV now that a corresponding Indian generic has long before come on line [15, 19].

Again, China's December 2008 law amendment stating that a Chinese patent can only be given to an invention or technology that is totally new worldwide looks like it would represent additional threat to brand industry interests [20].

Eventually, brand industry feelings may also arise from a proposed law in India to allow universities to patent publicly-funded research discoveries and increase collaboration with Indian industries [21].

On the whole, brand industry feelings sound quite understandable. Really, high-level standards in ARV drug manufacturing and marketing have already been achieved by the generic, mainly Indian, companies. Some key achievements are shown in Table $\mathbf{1}$, wherein we can notice
1) that patent pools for first-line FDC ARVs for adults are no longer needed in the developing countries, 2) that patent pools for first-line FDC ARVs for children are needless, although full alignment by generic producers with all paediatric ARV formulations and dosages listed in WHO's guidelines has yet to be reached, and 3) that a number of key FDC ARVs still are rolled out by the generic manufacturers only $[7-9,15,22]$.

Concerns of originator companies over patent pooling also ground on prospects alerting to the fact that UNITAIDClinton Foundation alliance has created a minefield for ARVs policies currently driven by the brand pharmaceutical sector. The Clinton Foundation HIV/AIDS Initiative (CHAI) is, indeed, increasingly lowering the prices of ARVs by partnering with UNITAID and generic pharmaceutical manufacturers [23-25].

In the meantime, lists of countries eligible for differential pricing have been made available by Abbott, Bristol-Myers Squibb, Boehringer-Ingelheim, Gilead, GlaxoSmithKline, Merck \& Co. Inc, and Roche brand enterprises: unfortunately, the prices they offer are almost always quite higher than the reduced ones by CHAI for the corresponding generics to countries in its consortium $[22,26]$.

It is risky for the brand corporations to keep prices higher than Clinton's, especially if the counterpart is a CHAI consortium member country. The magnitude of risk is perceivable by considering that:

some FDC ARVs, still solely produced by generic firms (Table 1), have been made available to resource-constrained countries only thanks to CHAI discounts [15].

- Clinton consortium is expected to add further countries to its 71 members (as of December 2008), so leading to far cheaper ARVs as a result of enhanced bulk procurement $[15,25]$.

Overall, the perspectives listed above are feared to possibly reshape or even overturn the trade balances bound up with profitable ventures currently working between originators and, mainly, Chinese and Indian drug makers as far as R\&D sectors are specifically concerned (see later) [27].

Again, whole insights above may explain the request by some brand companies for further incentives to be attached to a patent pool model recently proposed by UNITAID and focused, first and foremost, on ARV drugs [14, 28, 29] (available details in previous articles inside this Open AIDS Journal issue).

Intriguingly, brand industry positions towards patent pools for ARVs may also depend on strategies bound up with their pipelines for new ARV drug development. Understandably, exploitation of patent full rights until expiry could be an option where no new ARVs are in the pipeline. On the contrary, the more drugs are in pipeline, the more brand industry availability will expectedly emerge towards flexible transactions, so keeping up as much options as possible and avoiding major risks in the future. 
Table 1. Fixed-Dose Combination ARVs by Generic Manufacturers

- $\quad$ AZT/3TC: adult formulations by Aspen, Aurobindo, Cipla, Emcure, Hetero, Matrix, Ranbaxy and Strides. The Clinton Foundation has negotiated reduced prices with Cipla and Matrix. Paediatric formulation by Matrix.

- AZT/3TC/ABC: adult formulations by Aurobindo (co-pack), Cipla, Hetero, Matrix, and Ranbaxy. No paediatric formulations.

- AZT/3TC/NVP: adult formulations by Aspen (co-pack), Apotex, Aurobindo, Cipla, Hetero, Matrix, Emcure, Ranbaxy. The Clinton Foundation has negotiated reduced prices with Aurobindo, Hetero, Cipla and Matrix. Paediatric formulations by Matrix, Government Pharmaceutical Organization (GPO) and Ranbaxy. Not available from originator companies.

- D4T/3TC/NVP: the Clinton Foundation has negotiated with Aurobindo, Hetero, Matrix, Cipla and Ranbaxy reduced prices for adult formulations. Adult formulation also made by Emcure and Strides. Paediatric formulations by Cipla, Hetero, GPO, Emcure, and Ranbaxy (reduced prices in Clinton's consortium for versions by Cipla and Ranbaxy). Not available from originator companies.

- ABC/3TC: adult formulation by Cipla. Paediatric formulations by Matrix and Aurobindo (reduced prices in Clinton's consortium).

- D4T/3TC: adult formulations by Aurobindo, Cipla, Hetero, Matrix, Ranbaxy, Emcure, and Strides. Paediatric formulations by Cipla, Emcure and Ranbaxy. Not available from originator companies. Reduced prices in Clinton's consortium for versions by Aurobindo, Cipla, Hetero, Matrix, Ranbaxy, Strides.

- Heat stable LPV/RTV: adult formulations by Aurobindo, Emcure, Cipla and Matrix (reduced price for Aurobindo, Cipla and Matrix versions in the Clinton Foundation's consortium). Paediatric formulations by Aurobindo and Matrix. N.B.: generic soft gel capsule LPV/RTV are currently produced by Cipla and Hetero (no paediatric formulations).

- D4T/3TC+EFV: adult formulations by Cipla, Emcure, Strides and Ranbaxy. No paediatric formulations. Not available from originator companies.

- AZT/3 TC+EFV: adult formulations by Aurobindo, Cipla, Emcure, Ranbaxy. No paediatric formulations. Not available from originator companies.

- PMTCT: NVP+AZT: granule formulations by Strides. Not available from originator companies.

- TDF/FTC: adult formulations by Cipla, Emcure, Hetero and Matrix (reduced price for Matrix version in the Clinton Foundation's consortium). Not for paediatric use.

- TDF/3TC: adult formulation by Matrix and Cipla (reduced price in the Clinton Foundation's consortium). Not for paediatric use. Not available from originator companies.

- TDF/FTC/EFV: adult formulation by Matrix (reduced price in the Clinton Foundation's consortium), Emcure and Cipla. Not for paediatric use.

- TDF/3TC+EFV: adult formulation by Cipla. Not for paediatric use. Not available from originator companies.

- TDF/3TC/EFV: adult formulation by Matrix (reduced price in the Clinton Foundation's consortium). Not for paediatric use. Not available from originator companies.

- TDF/3TC+ATV+heat stable RTV (starting in 2010): by Mylan/Matrix (reduced price in the Clinton Foundation's consortium). Not available from originator companies.

$\mathrm{AZT}=$ zidovudine, 3TC = lamivudine, $\mathrm{ABC}=$ abacavir, NVP = nevirapine, $\mathrm{D} 4 \mathrm{~T}=$ stavudine, $\mathrm{LPV} / \mathrm{RTV}=$ lopinavir/ritonavir, $\mathrm{EFV}=\mathrm{efavirenz}, \mathrm{TDF}=$ tenofovir, $\mathrm{FTC}=\mathrm{emtricitabine}$, $\mathrm{ATV}=$ atazanavir, $P M T C T=$ prevention mother-to-child transmission

WHO prequalified ARVs (updated list) at [53].

Information mainly obtained from [15, 22].

Again, openings could happen when exchange for royalty payment, as in UNITAID model, would possibly compensate for profit losses bound up with the rolling out of generic FDC ARVs that include second-line principles whose patentability is being pursued by the brand patent owner (Table 1).

Additional food for thought could be solicited by relevant questions:

- What extent is the real originator companies's interest towards emerging markets where a number of welloff elites, who can afford out-of-pocket spending (at least 300 million people in India, many more in China), currently live?

- Owing to FDCs are no doubt the ARV therapy backbone, why should originator companies hesitate to boost patent pool strategies as set up for BristolMyers Squibb \& Gilead Sciences's ATRIPLA ${ }^{\circledR}$ (efavirenz, emtricitabine, and tenofovir FDC), to properly address at least adherence?

\section{GATHERING STEAM FOR AWARENESS}

On the whole, conflictual insights above would suggest the originator companies to increase awareness and take the lead towards shrewdly adopting UNITAID patent pool model. Otherwise, as seemingly foreseeable from trade\&policy world trends, their opportunities could be in jeopardy or reduced in the future.

Indeed, the agreement on TRIPs (Trade Related Aspects of Intellectual property Rights) of World Trade Organization (WTO) does not formally obstruct the UNITAID patent pool model [30, 31], while steadily increasing pro-pooling overpressure is registered from public opinion, mass media, NGO networks, UN Agencies, as well as from governments and firms in the developing countries. Taken together, these realities could result, if the brand multinationals did refuse to enter the pool, in enforced compulsory licenses (CLs) [11]. These would stand as detrimental to brand enterprise expectations, predictably due to tighter room for negotiations and constraining clauses over enjoyable royalties. Compulsory licensing (CL) would really be an option in such a case to force into reasonable terms patent holders deemed to be non-cooperative in the face of serious health risks.

CL feasibility would be, anyway, hard bet now that protectionist policies and Free Trade Agreements (FTAs) are still driven by USA and European Union (EU) in spite of recent WTO, G7 and G8 leaders warns and pledges against trade protectionism $[32,33]$. Nonetheless, in mid-long term perspective, CL feasibility could impose itself as a result of confluent factors, among which: 
- Weakening USA trade\&policy appeal over SouthEast Asia, South-America and Africa due to the emergence of strong competitors such as China, India, and Russia.

- Weakening USA attraction power and influence over international chessboard.

- $\quad$ Rising EU reliability through improved member governments alignment in operational and decisional patent-related issues [34].

- Increasingly mounting evidence of government CLs against first and second-line brand ARV single products $[4,15]$.

\section{TAILORING MODEL FOR EQUITABLY DRIVEN FREE WORLD MARKET}

Overall scenarios above look like they are enough to advise the originator companies that joining efforts into long-term shared strategy, as part of UNITAID patent pool, would be mandatory to fairly attune the interests of all counterparts (including end-users and generic and brandname enterprises).

Coherently, UNITAID model should play as key component of a more complex strategy up to going beyond UNITAID proposal itself and equitably countering brand market erosion deemed to follow the mere patent right giving up to the advantage of generic drug industry.

This strategy should encompass full availability on the market of second and third-line brand FDC ARVs as a result of partnerships between originator companies.

Actually, it appears that these directions, though at their beginning, have already been set in motion: contacts between originator companies seem, indeed, currently being underway as far as joint manufacturing and rolling out of second and third-line brand FDC ARVs are concerned [35]. This would make a difference, especially now that brand heat-stable RTV is about to become available [36].

Again, these brand moves would pull off substantial deal now that South industry high-level skills on innovation, manufacturing and marketing do entwine with steadily increasing both South-South cooperation examples and outsourcing models in North-South R\&D joint ventures [16, 27, 37-49].

Multinational pharma companies are, indeed, currently striking deals with Chinese and Indian drug researchers to outsource testing for drug candidates and replenish drug development pipelines, while accelerating, thanks to the efficiency of Eastern laboratories, a development process and saving billions of dollars in costs (in India, five $\mathrm{PhD}$ chemists can be employed for the cost of one in the West). Concurrently, Eastern researchers are benefitting through profit shares and intellectual property rights, while being aware that these collaborations will spur new breakthroughs in medical research and develop a local industry originally built on mere generic drugs [27].
Taken together, these realities mean that peer trade competition between wealthy and middle-income countries is already round the corner.

As core message, the whole insights above would urge partnerships between originator companies first to make newer FDC ARVs quickly available (including combinations aligned with WHO's recommendations), and allow patent pool agreements with generic counterparts (as per UNITAID model) to be negotiated straight afterwards.

This strategy looks like it would be up to attaining a really free and equitably driven world market.

Indeed, while securing the generic producers opportunities and equipment to make and roll out second and third-line (either for adults or children) new FDC ARVs, it would not prevent the generic and brand counterparts from negotiating mutually profitable VLs, if any. To the same extent, this strategy would be up to allowing the originator firms to still keep up competitiveness as far as bulk purchasing agreements for new FDC ARVs with CHAI-UNITAID are concerned.

Hopefully, the highlighted strategy should include getting round and lifting a clause in UNITAID patent pool model that would forbid selling to High Income Countries (World Bank defined) FDC generic ARVs resulting from patent pools. To this aim, compulsorily aligning prices of these generic formulations with the corresponding brand ones on wealthy markets should be enough measure against unfair competition.

Mutually, the model here should not prevent brand name FDCs from entering the developing countries, provided their prices align with those applied by CHAI-UNITAID for the corresponding generics [22].

Overall, the highlighted model would spread good treatment adherence all over the world, while scaling up, on sustained basis, equitable access to appropriate and affordable new FDC ARVs, with no discrimination between end-users in wealthy and resource-limited countries.

Again, upon brand industry angle of view, the compounded strategy here would allow to keep up R\&D standards and marketing power, while enjoying the advantages from new partnerships, avoiding risks of CLs, and predictably getting round the need for additional incentives to enter patent pools.

Upon generic industry perspective, instead, this model would extensively boost innovation, joint ventures and competitiveness also beyond the under-served markets.

The multi-pronged strategy envisaged in this contribution would recommend originator companies to improve their policies, while tackling evolutionary directions from emerging markets and bringing opportunities to the generic counterparts. So compounded, it would promote and enhance:

- $\quad$ For-equity dynamics in drug trading policies, while meeting the interests of generic and brand manufacturers. 
- $\quad$ Effective response to HIV resistance mutations urging availability of second/third-line FDC ARVs in lowincome countries.

- $\quad$ R\&D and international standard innovation plans.

- $\quad$ South-South and North-South partnerships.

- Opportunities for researchers working in developing countries.

- Domestic employment and national/international market increases.

- Indigenous capacity to generate, manage and use technology to address domestic health needs.

- $\quad$ Setting up of country-owned plants for generic ARVs in Sub-Saharan Africa, so adding strength for profitable negotiations, while drawing originator companies into more flexible agreements.

Fulfilment of prospects above will depend on crossing policies of multiple counterparts, including European Union, USA, China, India, Brazil, South Africa and Thailand' s government directions. While the end-results of these policies are hardly predictable, available trends seem to advise that the highlighted strategy would be an attuned way in long-term perspective, by complementing, rather than replacing, current regimens.

The strategy suggested here aligns with both the $61^{\text {st }}$ WHO's Assembly recommendations and G7 finance ministers, G8 and WTO's recent warnings and pledges against protectionist policies.

Clearly, the highlighted model would be only one factor among several in determining outcomes [15, 50-52].

It would impact, anyway, as a step ahead in establishing a new era: that actually asserting, through equitably driven free world market, the primacy of right to health over forprofit policies.

\section{CONTRIBUTORSHIP}

D. Dionisio conceived, designed and wrote the article.

V. Racalbuto and D. Messeri shared in the draft preparation and participated in overall interpretation, revision and harmonisation.

Author Note: While this paper was in final press stage, 12th Edition "Untangling the web of antiretroviral price reductions" was released at MSF website (http://utw. msfaccess.org/ 3 December 2009). Changes there do not affect the contents of this paper.

\section{REFERENCES}

[1] Sixty-first World Health Assembly 24 May 2008: Global strategy and plan of action on public health, innovation and intellectual property. Available from: http://www.who.int/gb/ebwha/pdf_files/ A61/A61_R21-en.pdf

[2] 't Hoen $\bar{E}$, von Schoen-Angerer T. A Patent Pool for Medicines. TheWorldToday.org 2009: 30-1. Available from: http://www.msfa ccess.org/resources/key-publications/key-publication-detail/?tx_ttn ews \% 5Btt_news\%5D=1522\&cHash=79c9cf6960 [Accessed: April 2009].
WHO, UNAIDS, UNICEF. Towards Universal Access: scaling up priority HIV/AIDS interventions in the health sector (June 2008 progress report). Available from: http://www.who.int/pub/towards universal access report 2008.pdf

isio D, Gass R, McDermott P, et al. What strategies to boost production of affordable fixed-dose antiretroviral drug combinations for children in the developing world? Curr HIV Res 2007; 5: 155-87. Available from: http://www.ingentaconnect.com/ content/ben/chr/2007/00000005/00000002/art00002 [Accessed: April 2009].

[5] MDG 8 Task Force Report: Delivering on the Global Partnership for Achieving the Millennium Development Goals, United Nations. New York, August 2008. Available from: http://www.un.org/esa/ policy/mdggap

[6] van Roey J, von Schoen-Angerer T, Ford N, Calmy A. How developing world concerns need to be part of drug development plans: a case study of four emerging antiretrovirals. Drug Discov Today 2008; 13: 601-5 Available from: http://www.msfaccess. org/reso urces/key-publications/key-publication-detail/?tx_ttnews\%5Bt $t$ news \% 5D=1437\&cHash=c7ed6240d0 [Accessed: April 2009].

[7] Vitoria M. WHO recommendations on preferred second-line antiretroviral drugs for adults and adolescents. Joint WHO/ UNAIDS informal consultation with pharmaceutical companies. Geneva, 16 December 2008. Available from: http://www.who.int/ hiv/amds/who recommen 2line art failure meeting.pdf

[8] Crowley S. WHO recommendations for $\overline{A R} V$ treatment in infants and children. Joint WHO/UNAIDS informal consultation with pharmaceutical companies. Geneva, 16 December 2008. Available from: http://www.who.int/hiv/amds/who_recommen_arv_treatment infants.pdf

[9] Memorandum: Proposed recommendations of PI list for the next revision of WHO model list of essential medicines (WHO, 25 November 2008). Available from: http://www.who.int/entity/ selection medicines/committees/expert/17/application/Review_pro tease.pdf

[10] Showalter B, Kurth T. New uses for patent pools (2008, Intellectual Property Today). Available from: http://www.iptoday.com/articles/ 2008-9-showalter.asp

[11] Kaplan W. Fostering R\&D and promoting access to medicines: locating common ground: operationalising patent pools for ARVs. New ICTSD series on New Opportunities through Innovation. 22-26 October 2007, Bellagio, Italy. Available from: www.iprs online.org/ictsd/Dialogues/ 2007-10-22/8\%20ThinkPiece Kaplan2.pdf

[12] ' $t$ Hoen E. The Global Politics of Pharmaceutical Monopoly Power (MSF, 2009). Available from: http:// www. msfaccess.org/main/ access-patents/the-global-politics-of-pharmaceutical-monopolypower-by-ellen-t-hoen/

[13] GSK should allow generic competition for HIV/AIDS drugs to address innovation, access problems in developing countries, opinion piece says. Kaiser Daily HIV/AIDS Report, 25 February 2009. Available from: http://www.kaisernetwork.org/DAILY_ REPORTS/print report.cfm?DR ID $=57152 \&$ dr cat $=1$

[14] UNITAID patent pool at Mexico City conference. 6 August 2008, Knowledge Ecology International-KEI. Available from: http://www. keionline.org/index.php?option $=$ com jd-wp\&Itemid $=39 \& p=135$

[15] Dionisio D, Fabbri C, Messeri D. HIV drug policies and South markets: settling controversies. Therapy 2008; 5: 707-17. Available from: http://www.futuremedicine.com/doi/pdfplus/10.2217/147507 08.5.5.707 [Accessed: April 2009].

[16] Engardio P. Chinese Scientists Build Big Pharma Back Home BusinessWeek. September 4, 2008. Available from: http://www. businessweek.com/print/magazine/content/08_37/b4099052479887.htm

[17] Pinheiro E, Vasan A, Kim JY, et al. Examining the production costs of antiretroviral drugs. AIDS 2006; 20 (13): 1745-52.

[18] Pinheiro ES, Antunes OA, Fortunak JM. A survey of the syntheses of active pharmaceutical ingredients for antiretroviral drug combinations critical to access in emerging nations. Antiviral Res 2008; 79: 143-65.

[19] Treatment access: Indian generic heat-stable ritonavir. NovemberDecember 2006, HIV Treatment Bulletin, I-Base published. Available from: http://www.i-base.info/htb/v7/htb7-12/indian.html

[20] Yue Y, Hepeng J. China gets in line on patent standards. 6 January 2009 , Science and Development Network. Available from http://www.scidev. net/en/news/china-gets-in-line-on-patent-standards.html 
[21] Padma TV. Patent pledge to Indian universities. Nature 2008; 456: 685-6. Internet http://www.nature.com/news/2008/081210/full/ 456685a.html (accessed April 2009)

[22] Untangling the web of antiretroviral price reductions: $11^{\text {th }}$ ed. July 2008: Campaign for Access to Essential Medicines. Medecins Sans Frontieres. Geneva, Switzerland. Available from: http://www. accessmed-msf.org/fileadmin/user_upload/diseases/hiv-aids/Untan gling_the_Web/Untanglingtheweb_July2008_English.pdf

[23] UNITAID and the Clinton HIV/AIDS Initiative announce new price reductions for key AIDS medicines. UNITAID Report, 17 April 2009. Available from: http://www.unitaid.eu/index2. php?o ption $=$ com_content $\&$ task $=$ view $\&$ id $=148 \&$ pop $=1$

[24] CHAI: partner and procurement countries, January 2008. Available from: http://www.clintonfoundation.org/partner-procurement-count ries.htm

[25] Clinton Foundation: Request for Proposals for Supply of UNITAID-Financed Pediatric and/or Adult Second-Line Antiretrovirals for period of March 2009 - February 2010 (December 15, 2008). Available from: http://www.clinton foundation.org/what-we-do/clinton-hiv-aids-initiative/informationcenter-resources

[26] Chien CV. HIV/AIDS drugs for Sub-Saharan Africa: how do brand and generic supply compare? PLoS ONE 2007; 3: e278. Available from: http://www.plosone.org [Accessed: April 2009].

[27] Engardio P, Weintraub A. Outsourcing the Drug Industry. BusinessWeek, September 4, 2008. Available from: http://www. businessweek.com/print/magazine/content/08_37/b4099048471329 .htm

[28] Bermudez J. Access to medicines and IPR: UNITAID moving towards a patent pool? UNITAID second consultative forum. Dakar, Senegal, 6 December 2008. Available from: http://www. unitaid.eu/index.php/en/NEWS/UNITAID-Consultative-Forum-20 08.html

[29] Cost benefit analysis for UNITAID patent pool. 20 June 2008, Knowledge Ecology International-KEI. Available from: http:// www.keionline.org/misc-docs/1/cost_benefit_UNITAID_pat ent_pool.pdf

[30] World Trade Organisation Overview: the TRIPS Agreement 2005; Available from: http://www.wto.org/English/tratop_e/ trips_e/intel 2_e.htm [Accessed: April 5th, 2009].

[31] Abbott FM, Reichman JH. The Doha round's public health legacy: strategies for the production and diffusion of patented medicines under the amended TRIPS provisions. J Int Econ Law 2007; 10: 921-87. Available from:: http://www.jiel.oxford journals.org/cgi/ content/abstract/10/4/921

[32] G-7 finance ministers vow to cooperate, resist protectionism. 18 February 2009, International Centre for Trade and Sustainable Development. Available from: http://ictsd.net/i/news/bridges weekly/41042/

[33] WTO warns against protectionism, promises increased monitoring (12 February 2009, International Centre for Trade and Sustainable Development). Available from: http://ictsd.net/i/news/bridges weekly/40499/

[34] STOA Conference on "Current Policy Issues in the Governance of the European Patent System", 17 March 2009, European Parliament, Brussels, Belgium. Available from: http://www.euro parl.europa.eu/stoa/events/workshop/20090317/default_en.htm

[35] GSK, Pfizer announce combined HIV/AIDS drug business. Kaiser Daily HIV/AIDS Report, 16 April 2009. Available from: http://www.kaisernetwork.org/daily_reports/print_report.cfm?DR_I $\mathrm{D}=58033 \& d \mathrm{dr}_{-} \mathrm{cat}=1$

[36] New heat-stable Norvir tablet sent to FDA for approval (POZ\&AIDS Meds Com, 28 January 2009). Available from: http://www.poz.com/printView.php?page=/articles/hiv_norvir_rito navir_1667_16021.
[37] Deen T. Quantum leap in South-South Investments and Trade 19 January 2008. Inter Press Service News Agency. Available from: http://www.ipsnews.net/print.asp?idnews $=40799$

[38] ARVIR technology 10 June 2008. Available from: http://www. arvir.co.za/?q=con,6,technology

[39] China, Singapore ink free trade deal. 30 October 2008, International Centre for Trade and Sustainable Development. Available from: http://ictsd.net/i/news/bridgesweekly/32382/

[40] Padma TV. Support pledged for Southern genomics research (30 September 2008, Science and Development Network. Available from: http://www.scidev.net/en/news/support-pledged-for-southern-geno mics-research.html

[41] African leaders agree to work toward 26-country trade bloc. 30 October 2008, International Centre for Trade and Sustainable Development. Available from: http://ictsd.net/i/news/bridges weekly/32373/

[42] IAVI announces funding for Taiwan HIV/AIDS research team. Kaiser Daily HIV/AIDS Report, 22 October 2008. Available from: http://www.kaisernetwork.org/DAILY_REPORTS/print_ report.cfm?DR ID $=55130 \&$ dr cat $=1$

[43] Brazilian president arrives in Mozambique to launch antiretroviral production initiative. Kaiser Daily HIV/AIDS Report, 17 October 2008. Available from: http://www.kaisernetwork.org/DAILY REPORTS/print_report.cfm?DR_ID $=55042 \& d r$ cat $=1$

[44] Osama A. Opportunities and challenges in South-South collaboration. Science and Development Network, 14 May 2008. Available from: http://www.scidev.net/en/science-and-innovationpolicy/policy-briefs/opportunities-a...

[45] Brazil to produce generic version of Merck's antiretroviral efavirenz (Kaiser Daily HIV/AIDS Report, 18 September 2008). Available from: http://www.kaisernetwork.org/DAILY_REPORTS/print_report.cfm?D R_ID $=54520 \& d r \_c a t=1$

[46] Ethiopia - Pharmaceutical factory built with 90 million birr inaugurated (EthioBlog, 24 September 2007). Available from: http://nazret.com/blog/index.php?title=ethiopia_pharmaceutical_fa ctory_inaugura\&m

[47] China to sign FTA with Peru; other deals may soon follow. 19 November 2008, International Centre for Trade and Sustainable Development. Available from: http://ictsd.net/i/news/bridges weekly/34096/

[48] Swaziland to purchase antiretrovirals from Uganda to address country's HIV/AIDS epidemic, King Mswati says. Kaiser Daily HIV/AIDS Report, 11 July 2008. Available from: http://www. kaisernetwork.org/DAILY_REPORTS/print_report.cfm?DR_ID=5 $3235 \& d r \_$cat $=1$

[49] Melon C, Ray N, Chakkalackal S, et al. A survey of South-North health biotech collaboration. Nat Biotechnol 2009; 27: 229-232. Available from: http://www.nature.com/nbt/journal/v27/n3/pdf/nbt 0309-229.pdf [Accessed: April 2009].

[50] Juma C. Learn to earn. Nature 2008; 456:15-7. Available from: $\mathrm{http}: / / w w w . n a t u r e . c o m / n a t u r e / j o u r n a l / v 456 / \mathrm{n} 1 \mathrm{~s} /$ full/twas08.15a.html [Accessed: April 2008].

[51] Caudron JM, Ford N, Henkens M, Mace C, Kiddle-Monroe R, Pinel J. Substandard medicines in resource-poor settings: a problem that can no longer be ignored. Trop Med Int Health 2008; 13: 106272. Available from: http://www.msfaccess.org/ resources/keypublications/key-publication-detail/?tx_ttnews\%5Btt_news\%5D=1 485\&cHash= 98a07af910 [Accessed: April 2009].

[52] Toward a new era of intellectual property: from confrontation to negotiation. A report by the International Expert Group on Biotechnology, Innovation and Intellectual Property. McGill University, Montreal, Canada, September 2008. Available from: http://www.theinnovationpartnership.org/data/ieg/documents/report /TIP_Report_E.pdf

[53] WHO list of prequalified medicinal products 2009. Available from: http://healthtech.who.int/pq/default.htm 